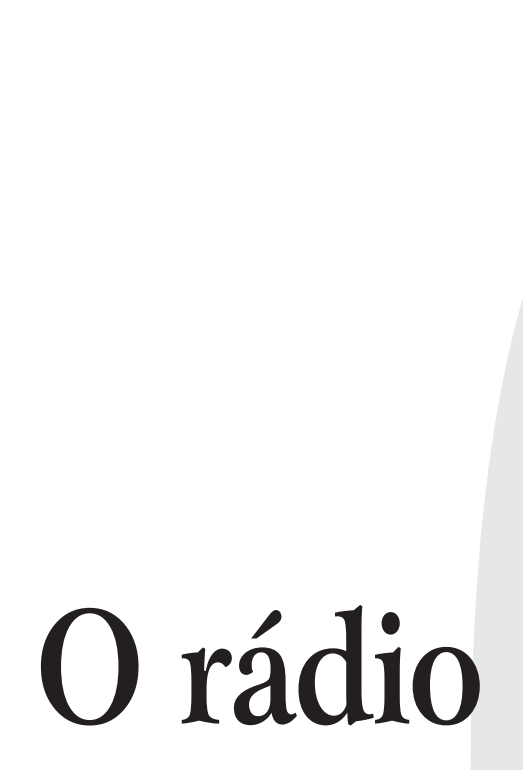

\title{
e a música
}

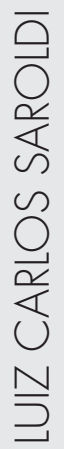

\section{A FESTA NO CASTELO}

LUIZ CARLOS SAROLDI

foi professor de

Radialismo na Escola de Comunicação da UFRJ. É radialista, dramaturgo, pesquisador musical e autor de, junto com Sonia Virgínia Moreira, 0 Brasil em Sintonia (Zahar).

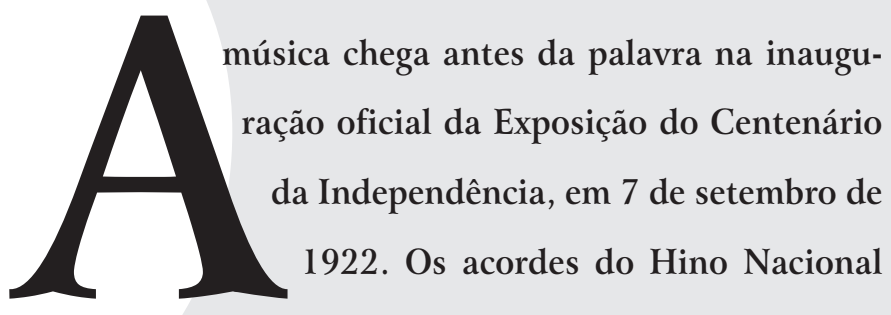
Brasileiro constituem o primeiro som a sair dos altofalantes instalados nos quase $450 \mathrm{mil} \mathrm{m}^{2}$ da esplanada aberta no centro da então capital da República e a ser retransmitido pelos 80 aparelhos de rádio instalados pelo governo em Niterói, Petrópolis e São Paulo. 
O novo espaço urbano providenciado pelo prefeito Carlos Sampaio resultara do desmonte do Morro do Castelo e vinha completar a modernização do Rio de Janeiro, simbolizada pela abertura da Avenida Central, obra que em 1905 consagrou o engenheiro Pereira Passos.

A composição de Francisco Manuel da Silva tinha uma história curiosa. Fora escrita em 1822, mas ficara em segundo plano, ofuscada pelo Hino da Independência, composto por D. Pedro I. Somente em 1831 , após a abdicação de Pedro I e a coroação de seu filho, a obra de Francisco Manuel da Silva seria reconhecida como símbolo sonoro do país, embora continuasse de execução apenas instrumental. Os versos que conhecemos hoje foram escritos por Osório Duque Estrada em 1909 - quase oitenta anos depois - e só oficializados pelo Congresso Nacional às vésperas da abertura da Exposição do Centenário. Propagando-se da Praça 15 à ponta do Calabouço e chegando à Praça Paris, as notas do Hino Nacional Brasileiro antecederam a transmissão do discurso com que o presidente Epitácio Pessoa abriu oficialmente a grande festa da ex-colônia portuguesa.

A escolha do rádio como veículo da palavra presidencial era mais uma prova do compromisso da República brasileira com a modernidade. $\mathrm{O}$ invento que domesticara as ondas hertzianas entrara em transmissões regulares na Europa e nos Estados Unidos havia apenas dois anos, logo constituindo um acontecimento tão apaixonante quanto o cinema, com a vantagem de chegar ao ouvinte em tempo real 
e com a sonoridade que a sétima arte ainda não tinha. O Brasil acabara de incorporar ao posto emissor dos Correios e Telégrafos, na Praia Vermelha, uma estação radiofônica de 500 watts fornecida pela Western Electric, ao mesmo tempo que a Westinghouse instalara no alto do Corcovado outra emissora da mesma potência, a título de demonstração, colocando-a a serviço do governo brasileiro para a mostra internacional.

A repercussão dessa primeira transmissão radiofônica foi registrada pela imprensa no dia seguinte, conforme a grafia da época e o estilo de A Noite (8/set./1922, cit. Lopes, 1972, p. 7):

"Uma nota sensacional do dia de ontem foi o serviço de rádio-telephonia e telephone alto-falante, grande atrativo da Exposição. O discurso do Sr. Presidente da República, inaugurando o certamen foi, assim, ouvido no recinto da Exposição, em Nictheroy, Petrópolis e em São Paulo, graças à instalação de uma possante estação transmissora no Corcovado e de aparelho de transmissão e recepção, nos logares acima. [...] À noite, no recinto da Exposição, em frente ao posto e Telephone Público, por meio do telephone alto-falante, a multidão teve uma sensação inédita: a ópera Guarany de Carlos Gomes, que estava sendo cantada no Theatro Municipal, foi, ali, distinctamente ouvida, bem como os aplausos aos artistas. Egual cousa succedeu nas cidades acima”.

Era a segunda emoção musical proporcionada pela radiodifusão em sua chegada ao Brasil, agora representada pela ópera de autor brasileiro brindada com elogios de Verdi e que dera a Carlos Gomes o título de cavaleiro da Coroa da Itália. Um toque erudito, fino, de elite, ou "de Primeiro Mundo" - como se diria em um futuro distante.

Curiosamente, ao mesmo tempo, oito artistas populares do Brasil conquistavam o público europeu apresentando-se durante seis meses em um dos cabarés mais sofisticados de Paris. Tinham como cicerone o dançarino que introduzira o maxixe na Europa dez anos antes e que atendia pelo nome artístico de Duque (Antonio Lopes de Amorim Dinis, 1884-1953). O líder do conjunto Oito Batutas era um negro alto e risonho, bom de sopro, de choros, sambas e valsas, apelidado desde pequeno de Pixinguinha. Por coincidência, Alfredo da Rocha Viana Filho (1898-1973) viria a se tornar um dos talentos mais requisitados do teatro, do disco e, também, do rádio brasileiro.

\section{O PROFESSOR E A NOVA AVENTURA}

Em setembrode 1922 Edgard RoquettePinto se preparava para comemorar 39 anos. A proximidade dos 40 não o assustava, embora reconhecesse não ter a mesma disposição atlética que lhe permitira acompanhar, dez anos antes, durante quatro meses, a expedição comandada pelo tenente-coronel Rondon ao Planalto Central, enfrentando cobras e lagartos em busca de índios parecis e nhambiquaras avessos ao contato com os brancos. O esforço valera uma valiosa contribuição sobre os indígenas para o Museu Nacional, mais notas, desenhos, gravações e fotos para documentar a obra de antropologia a que deu o título de Rondonia.

A atividade científica do mestre se completava com o cargo de secretário da Academia Brasileira de Ciências, presidida pelo amigo Henrique Morize. Nas horas vagas lia as obras de Goethe no original, escrevia versos que não tinha pressa de publicar, cantava com voz de barítono e ainda tocava piano - tudo isso de modo competente, segundo dizem, embora seus versos não alcançassem o prestígio de sua prosa.

Não se sabe com quem Roquette-Pinto compareceu à festa do Castelo. É certo, porém, que a ele devemos uma versão mais crítica do que a dos jornais a respeito da transmissão inaugural no recinto da Exposição do Centenário, registrando o pouco interesse popular pelas demonstrações experimentais de radiofonia (Roquette-Pinto, 1953): 
"Muito pouca gente se interessou. Creio que a causa principal desse desinteresse foram os alto-falantes instalados na Exposição. [...] Ouvindo discursos e música reproduzidos no meio de um barulho infernal, tudo roufenho, distorcido, arranhando os ouvidos... era uma curiosidade sem maiores conseqüências".

O certo, porém, é que essas turbulências não impediram o cientista de se engajar em uma nova missão: a de dar ao Brasil sua primeira emissora de rádio. Fundada oficialmente em 20 de abril de 1923, a Rádio Sociedade do Rio de Janeiro PR-1-A nascia sob o patrocínio da Academia Brasileira de Ciências, com a contribuição de mais de trezentos sócios-efetivos. No dia $1 \cong \mathrm{de}$ maio entrava no ar em caráter experimental a nossa primeira emissora, utilizando por empréstimo a estação da Praia Vermelha, embora só viesse a funcionar regularmente a partir de 7 de setembro, instalada no pavilhão antes ocupado pela Tchecoslováquia na Exposição do Centenário.

Na cabine de comando de sua nova aventura, Roquette-Pinto estimulava seus companheiros a produzir e apresentar programas, geralmente sobre temas científicos, cívicos e culturais, dentro do espírito do rádio educativo. Ele mesmo ocupava o microfone como nosso primeiro speaker ou mestre-de-cerimônias, apresentando palestrantes e declamadores, pianistas e cantores, ou transmitindo e comentando as notícias publicadas nos matutinos em seu Jornal da Manhã.

Em uma dessas ocasiões seu caminho se cruzou com o de um jovem aficionado do canto lírico, a quem agradeceu o empréstimo de discos da ópera Rigoleto, de Verdi, "colaboração do nosso sócio e amigo Sr. Renato Murce”. Em suas memórias, escritas cinqüenta anos depois, o criador de programas como Papel Carbono e Alma do Sertão relembrou sua estréia ao microfone da emissora pioneira, ainda como amador (Murce, 1976, pp. 20-1): “Eu mesmo apresentei-me na Rádio Sociedade, a convite do meu dileto amigo Roquete Pin- to, em junho de 1924 (data que assinalo como a minha entrada para o sem-fio), com um programa operístico".

Apesar de seu entusiasmo pelo canto e sua admiração por Roquette-Pinto, Renato Murce reconheceu que a opção do mestre por uma programação austera, voltada exclusivamente para a educação e a cultura, caracterizava o rádio como um veículo de elite, "não atingindo a massa" (Murce, 1976): “Assim, os primeiros anos do rádio foram difíceis: muita música clássica, muita ópera, muita 'conversa fiada' e a colaboração graciosa de alguns artistas da sociedade".

Tal rigidez seria quebrada com a rápida multiplicação de emissoras por todo o país, embora ainda constituídas como clubes, sociedades ou educadoras, sem autorização legal para veicular mensagens comerciais, ou "reclames". Em seu terceiro ano no ar, a Rádio Sociedade cede à insistência dos ouvintes e admite, a contragosto da diretoria, "música leve" em suas transmissões. Outro exemplo de flexibilidade é dado pela Rádio Educadora de São Paulo, que já em 1927 favorecia a música popular gravada ou ao vivo em sua programação, segundo Maria Elvira Bonavita Federico (1982).

Ao longo da década de 1920 os brasileiros constatam que a radiomania não é uma curiosidade passageira, "sem maiores conseqüências”. Graças ao rádio, são incorporadas à linguagem cotidiana palavras novas, como "antena", "ebonite", "galena", "sem-fio", algumas até empregadas com malícia ou duplo sentido, como "microfone”. E a própria música popular encontra no rádio uma nova fonte inspiradora.

“Canto/ bem junto ao microfone para poder dizer/ tudo o que você já me fez sofrer...

Meu amor/ ligue seu rádio baixinho assim procure ouvir a voz da minha dor pedindo um pouquinho de amor..." ("Canto ao Microfone", marcha, André Filho, 1936).

Roquette-Pinto calculou, em um de seus ensaios, a existência de 30 mil receptores 
de rádio no Brasil em 1926 (Roquette-Pinto, 1927). Um número certamente bem maior em 1930, quando cinco estações funcionam na capital da República: Sociedade, Clube do Brasil, Educadora do Rio de Janeiro, Mayrink Veiga e Philips, esta trazida pela empresa holandesa fabricante de discos e aparelhos sonoros. A disputa de audiência leva os dirigentes de emissoras a buscar novas atrações, abrindo espaço a talentos vindos do disco, do circo ou do teatro de revista. As vozes poderosas de cantores como Francisco Alves, Vicente Celestino e Augusto Calheiros e da dupla sertaneja Jararaca e Ratinho terão de se adaptar à sensibilidade dos microfones.

O governo provisório trazido pela Revolução de 1930 estabelece bases para a concessão e operação de emissoras em todo o país, incluindo a publicidade no ar. Já em seu primeiro ano na chefia do governo, Getúlio Vargas regula a outorga de concessões, fixa normas técnicas e institui inserções comerciais até o máximo de $10 \%$ do tempo de transmissão de cada emissora. O projeto de $27 \mathrm{de}$ maiode 1931 é aprovadopeloDecreto 21.111, de 1 de março de 1932, marco decisivo na história da radiocomunicação no Brasil. A preocupação dos novos governantes quanto à importância do rádionaquele momento também repercute a crise provocada pelo crack da Bolsa de Nova York, em 1929, e antecipa as tensões políticas internacionais em gestação, prestes a explodir ao longo da década de 1930.

\section{VENDEDOR ABRE UMA ESCOLA DE RÁDIO}

Sem ter tido tempo nem condições familiares para receber uma educação formal mediana, o pernambucano Ademar Casé (1902-93) entra nessa história devido a seu fracasso como corretor de terrenos. Embora não tivesse talento para o canto nem tocasse qualquer instrumento, e a idéia de falar ao microfone lhe fosse paralisante, Casé enveredou pela venda de aparelhos de rádio da marca Philips, logo conquistando a confiança da empresa pelos resultados alcançados, graças a um artifício mercadológico. Depois de consultar o catálogo de telefones de determinada rua, o vendedor escolhia as casas de melhor poder aquisitivo para deixar um receptor sem compromisso, a título de "experiência", comprometendo-se a voltar dois ou três dias depois. Conquistada pelo novo equipamento doméstico, a família convencia o dono da casa a adquirir o aparelho, ainda que a prestações.

Animado com o sucesso de vendas, Casé passou a sintonizar as emissoras de ondas curtas e a comparar o dinamismo das emissões da BBC e da NBC com o rádio ainda acanhado do Rio de Janeiro. Imaginava como suas vendas aumentariam se tornasse mais atraente a programação da Philips, então tentando competir com a Mayrink Veiga, “a sua PRA 9".

O programa mais popular da época era produzido e apresentado na Mayrink pelo locutor Waldo Abreu, também produtor e corretor de anúncios. Hábil no improviso, Abreu se orgulhava de ser "o locutor que não lê" e fazia de cada anúncio algo tão espetacular quanto o salto de um trapezista de circo, sem rede. Por seu Esplêndido Programa passavam os cartazes da época, como Francisco Alves, Mário Reis, Augusto Calheiros ou a jovem Carmen Miranda. O pagamento de talentos era feito através de cachês, quando havia dinheiro, já que somente os speakers tinham alguma estabilidade, por identificarem as emissoras com suas vozes.

Contando com uma certa poupança, Casé resolveu investir no aluguel de tempo na Philips para pôr em prática uma programação diferente. Supriu a falta de contatos no meio artístico com a colaboração do cantor Silvio Salema, encarregado de arregimentar artistas, sempre que possível mesclando nomes de prestígio com gente nova, em geral rapazes e moças de classe média para cima, que não precisavam "daquilo" para comer. Muitos desses jovens preferiam se apresentar em grupos, comoo trio Irmãos Tapajós, ou os seis rapazes 
Das quatro horas compradas à Philips para transmissão do programa, Casé reservou as duas últimas para a música erudita. Mas logo descobriu que os telefones da emissora, que tilintavam durante o desfile de astros da música popular, agora permaneciam mudos. Passou então a reduzir esse espaço, só voltando a programar músicos ou cantores de projeção internacional quando em visita ao Rio, como fez com o pianista Brailowski. Estreando na Philips em fevereiro de 1932, o Programa Casé passou por sete emissoras cariocas em seus quase vinte anos no ar, mas teve seu período áureo durante oito anos na Mayrink Veiga, na década de 1940. Até mesmo a dramaturgia radiofônica foi explorada pelo programa, primeiro com a adaptação de romances famosos e mais tarde com o gênero policial.

Nessa escola prática de rádio também nasceu o embrião de nossos anúncios cantados, os jingles, graças à iniciativa do compositor Nássara, então redator e locutor do programa. Ao ler uma quadrinha que enaltecia os produtos da Padaria Bragança, em Botafogo, Nássara não resistiu e entoou um fado ao microfone, no melhor sotaque português : “Ó padeiro desta rua / tenha sempre na lembrança / não me traga outro pão / que não seja o pão Bragança”.

\section{"MAMÃE, VOU CANTAR NO RÁDIO!"}

No começo os anunciantes resistiam à idéia de investir em um veículo em que as palavras se perdiam no ar, sem a consistência da mídia impressa. Aos poucos, no entanto, a popularidade dos principais programas e a idolatria em torno de artistas e produtores conquistam espaço nos jornais e revistas, surgindo publicações especializadas, como o semanário Sintonia, dirigido pelo jornalista Gilberto de Andrade.

As empresas jornalísticas resolvem incorporar emissoras de rádio, solicitando concessões. A organização Diários Associados, de Assis Chateaubriand, prepara a inauguração das rádios Tupi, no Rio, e em São Paulo, o conde Pereira Carneiro faz o mesmo com a PRF 4, Rádio Jornal do Brasil, e A Noite assegura o prefixo PRE 8 para a Rádio Nacional, a ocupar o $22^{\circ}$ andar de seu edifício-sede, na Praça Mauá 7.

A vinda do locutor César Ladeira para a direção artística da Mayrink Veiga, em 1933, traz para o rádio do Rio de Janeiro mais prestígio e seriedade profissional, valorizando o elenco da emissora com contratos de exclusividade e pagamento de salários mensais, em substituição aos cachês.

O momento coincide com a implantação da política trabalhista de Vargas, entregue a um ministério próprio e com a instituição de carteiras profissionais, entre outras medidas. A confiança de anunciantes e agências se reflete gradativamente no volume de "reclames" e patrocínios. Para descobrir novos talentos a preços módicos e atrair audiência com o mínimo de investimentos, surge um gênero radiofônico de vida longa e boa receptividade: o programa de calouros.

O custo de produção era pequeno, já que todas as emissoras, mesmo modestas, tinham em seu elenco um pianista e um conjunto regional (dois violões, cavaquinho e pandeiro, mais um instrumento de sopro), quase sempre liderados por mestres como o flautista Benedito Lacerda ou o clarinetista Luiz Americano. Bastava convocá-los para ensaiar rapidamente os inscritos e escalar um speaker para receber os candidatos e expô-los ao julgamento da platéia.

Os aspirantes ao estrelato menos dotados se arriscavam a ser interrompidos bruscamente por um sinal sonoro, fosse o grasnar de um pato, o soar de um gongo ou uma buzinada. Os cantores de banheiro pouco tinham a perder, e os mais habilitados sonhavam com o acesso ao mercado de trabalho artístico, compensação maior do que o prêmio oferecido ao candidato vencedor. Em uma dessas audições, apresentada pelo locutor Heber de Bôscoli na Rádio Cruzeiro do Sul do Rio, o candidato aprovado recebia um prêmio original: levava para casa um pato... vivo. A ave permanecia no palco durante o desfile de calouros, sujeita 
a incontinências que divertiam a platéia. Este detalhe foi eliminado quando o animador se transferiu para a Rádio Nacional, anos depois, levando a idéia de A Hora do Pato. Então foram criados tronos e coroas para os vencedores, além de prêmios em dinheiro; os reprovados eram interrompidos pela gravação em que o ator Cahuê Filho imitava o esbravejar do bicho, cassando os desafinados.

O pioneirismo no gênero deve ser creditado ao locutor e radioator Celso Guimarães (1907-73). Ainda em 1933, na PRB 6, Rádio Cruzeiro do Sul de São Paulo, Celso lançou Os Calouros do Rádio, idéia colhida no jornal norte-americano Variety, em artigo sobre o sucesso do programa A Hora do Amador, de um tal Major Bowles, na pequena estação WHN, de Nova York. Em suas memórias, Celso registrou a participação em um desses programas do candidato a cantor de tangos Pablo Gonzales, mais tarde revelado como o humorista Silvino Neto (1913-91), criador de A Pensão da Pimpinela (Guimarães, 1950).

Também de grande sucesso foi a série Peneira Rodine, na Rádio Cultura de São Paulo. Entre os vencedores do programa figura o cowboy do rádio, Bob Nelson (Nelson Peres). Com sua adaptação de “Oh, Suzana", de Stephen Foster, e uma fantasia de vaqueiro comprada na Casa Sloper, Bob Nelson partiu a galope para o palco do Cassino Atlântico, do Rio, e dali para longos anos no auditório da Rádio Nacional.

Celso Guimarães também seria o mestre-de-cerimônias de outro programa do gênero ao se transferir para o Rio de Janeiro, contratado pela Rádio Nacional. Em 1937 estreava na PRE 8 Raio K em Busca de Talentos. Os candidatos ao prêmio de conto de réis, o maior já oferecido por qualquer emissora brasileira, eram submetidos a provas parciais e finais. Uma comissão julgadora selecionava cantores, imitadores, declamadores e radioatores. No quarto programa da série a vitória coube a um casal vindo de Niterói, a atriz Isis de Oliveira e o ator Altino Diniz, logo aproveitados no elenco da emissora, onde permaneceram até se aposentarem.
A criação do programa de variedades Horas do Outro Mundo, produzido e apresentado por Renato Murce na Philips, em 1932, transformou-o, afinal, em um profissional de rádio. Preocupado em descobrir novas atrações para seu elenco, ele revelou no pianista e compositor Ary Barroso habilidades de humorista e locutor. Anos depois, já no posto de diretor artístico da Rádio Clube do Brasil, emissora com um cast pequeno mas eficiente, Renato encarregou o locutor Arnaldo Amaral de apresentar os calouros de Pescando Estrelas, enquanto criava Papel Carbono, celeiro de novos cantores, humoristas e músicos. A proposta se baseava na imitação de nomes consagrados, e os concorrentes eram pré-selecionados e ensaiados, sem que fossem interrompidos. Segundo ele, já na estréia o programa revelou o humorista José Vasconcelos e o sanfoneiro Luiz Gonzaga. Curiosamente, a idéia de Papel Carbono ocorrera a Renato Murce no cinema, ao assistir a uma comédia norte-americana na qual um diretor de rádio, abandonado por seu elenco sem aviso prévio, partia para a imitação de seus colegas.

Além de um fator de aproximação do público com as emissoras e seus artistas, o programa de calouros trazia o embrião de outro filão econômico e promocional do rádio, os programas de auditório. Os horários abertos à presença dos fãs deram uma nova moldura sonora às transmissões, agora aquecidas pelos aplausos e risos da platéia e a empatia dos animadores. Diante do público, cantores e compositores podiam testar a comunicabilidade de suas criações, antes de chegarem aos estúdios de gravação.

O modelo do gênero fora posto em prática em 1943, na Nacional, no horário de $11 \mathrm{~h}$ da manhã, inicialmente em duas produções. Às terças, quintas e sábados partia o Trem da Alegria, pilotado por Heber de Bôscoli, Yara Sales e Lamartine Babo. Conhecidos por sua magreza, eles formaram o Trio de Osso, mas dispunham de vitalidade para produzir audições diárias de duas horas, com música, brincadeiras e distribuição de prêmios. O mesmo horário era ocu- 
pado às segundas, quartas e sextas pelo Programa Paulo Gracindo, em que o ator assumia o papel de animador de auditórios com a mesma competência do galã de novelas. Quando o Trem da Alegria levou sua tripulação a trilhar outros caminhos, trocando a Nacional pela Mayrink Veiga, Gracindo assumiu o horário de segunda a sábado, ainda irradiando o programa do Teatro Carlos Gomes, de quase 2 mil lugares. No entanto, voltaria a se concentrar no auditório nas tardes de sábado, até ceder o posto ao seu locutor auxiliar, César de Alencar (1917-90), ao deixar a PRE 8 por um convite irrecusável da Rádio Tupi.

A fórmula estava prestes a chegar ao apogeu, com filas em busca de ingressos para a platéia da Nacional, e anunciantes aguardando espaço para patrocinar as atrações do Programa César de Alencar. O desfile musical contava com acompanhamentos da orquestra do maestro Chiquinho e do regional de Dante Santoro, secundando Emilinha Borba, Blecaute, Marlene, Luiz Vieira, Ademilde Fonseca, Francisco Carlos, Neuza Maria, Jorge Veiga, Nuno Roland e tantos outros. Ainda eram marcas do programa o sanfoneiro Pedro Raimundo, com a rancheira "Adeus, Mariana” e seu traje de gaúcho, logo seguido por Luiz Gonzaga, seu chapéu de couro e suas parcerias com Humberto Teixeira e Zé Dantas. De efeito certo eram as intervenções dos conjuntos vocais Os Cariocas, Quatro Ases e um Coringa e Os Trigêmios Vocalistas - estes, além de cantar e tocar, ainda sapateavam.

À medida que se ampliava o tempo do programa para admitir novas atrações e patrocinadores, também se multiplicavam as críticas da imprensa, acusando os produtores e animadores de auditório de confundirem alegria com histeria, transformando a disputa dos fã-clubes num caldeirão de idolatrias e egocentrismos. Disso seria exemplo a manipulação promovida por um empresário imaginoso chamado Di Veras, capaz de vestir Cauby Peixoto com ternos que não resistiam ao primeiro toque de adolescentes subnutridas, deixando o cantor de cuecas e camiseta em plena Avenida Rio Branco.
Embora procedessem os argumentos, os programas de auditório foram um dos instrumentos que permitiram às emissoras manter seus quadros funcionais e equipamentos, e ainda investir em gêneros culturais de menor aceitação publicitária. O equilíbrio entre atrações de apelo popular e produções mais sofisticadas foi um dos segredos da administração do jornalista e advogado Gilberto de Andrade na direção da Rádio Nacional, após a encampação da empresa A Noite pelo governo brasileiro.

\section{O PONTO DE EQUILÍBRIO EM TEMPOS INSTÁVEIS}

Em 3 de setembro de 1939 Reino Unido, França, Austrália e Nova Zelândia declaram guerra à Alemanha, dois dias depois de Hitler invadir a Polônia. Era o começo da Segunda Guerra Mundial. Um conflito mais do que anunciado; as sucessivas crises da década de 1930 repercutiam até mesmo na Argentina e no Brasil. Aqui o fascismo se expandira sob o integralismo, culminando em 1938 com o fracassado assalto ao Palácio Guanabara.

Mesmo assim, o Decreto-Lei 2.073, assinado por Getúlio Vargas em 3 de março de 1940, não deixou de causar espanto. Afinal, como num passe de mágica, passavam a pertencer ao governo toda a rede ferroviária da Companhia Estrada de Ferro São PauloRio Grande, terras no Paraná e em Santa Catarina, o edifício de A Noite, seus jornais e revistas e ainda a Rádio Nacional. O mesmo decreto nomeava para superintendente das Empresas Incorporadas ao Patrimônio da União um militar, coronel Luiz Carlos da Costa Netto. Assumia a direção da Nacional o jornalista e advogado Gilberto Goulart de Andrade (1892-1949), colaborador de $A$ Noite e ex-diretor das revistas Sintonia e $A$ Voz do Rádio. Poeta e comediógrafo, Andrade também organizara a censura teatral e era promotor do controvertido Tribunal de Segurança Nacional.

A notícia da intervenção sobressaltou 
os funcionários da PRE 8 , temerosos de desemprego. Mas, já na primeira reunião, o diretor conquistou a confiança de seus principais colaboradores ao assegurar a estabilidade da empresa e acenar com a perspectiva de um papel mais ambicioso para a PRE 8, talvez equivalente ao das rádios estrangeiras, como a BBC de Londres, há dois anos atuando em ondas curtas com seu serviço brasileiro.

A notícia tranqüilizou especialmente o diretor artístico José Mauro, de 25 anos, com casamento marcado para dali a 15 dias, e que havia sido indicado para o cargo na administração anterior, com o apoio de Almirante e seus companheiros, tal o seu talento e entusiasmo pela profissão. Ao mesmo tempo, Gilberto de Andrade propôs reforçar o elenco da emissora, aceitando as indicações dos nomes dos maestros Lírio Panicali e Léo Peracchi. E antecipou sua decisão de instituir uma seção de estatística na Nacional, a fim de traduzir em números e gráficos os horários a serem oferecidos aos anunciantes. Conhecido pelo laconismo, Radamés reproduziu, décadas mais tarde, a frase com que Gilberto de Andrade estimulava a criatividade de seus liderados: "Vocês fazem agora o que quiserem: gastem o dinheiro que tiver aí, não precisa guardar" (Especial JB, 1977).

Ao que tudo indica, Gilberto de Andrade tivera tempo para amadurecer suas observações e seus projetos antes de assumir a direção. A regulamentação decretada em 1932 levara Roquette-Pinto a reconhecer a impossibilidade de manter a Rádio Sociedade com a contribuição mensal dos associados. Por isso resolvera devolver a concessão ao governo, apenas exigindo que este preservasse a emissora de injunções políticas, religiosas ou comerciais. A solução viria com a passagem do prefixo PRA 2 , seus bens e equipamentos para a área do ministro Capanema, surgindo, assim, a Rádio Ministério da Educação, administrada pelo Serviço de Radiodifusão Educativa. O compromisso estatal com o rádio educativo abria outros caminhos para a Nacional, que podia competir no mercado publicitário e reinvestir os lucros na expan- são de seus serviços.

Até então a PRE 8 não conseguira preencher completamente as expectativas de seu lançamento com o apoio promocional de A Noite, independentemente dos valores em seu elenco. O terreno escolhido para instalação da torre e do transmissor Philips de $25 \mathrm{~kW}$ se mostrou inadequado, exigindo a transferência para outro local. Por isso não conseguira ameaçar a liderança da Mayrink Veiga, centrada no carisma de César Ladeira, Carmen Miranda e o Bando da Lua, Ciro Monteiro e Odete Amaral, e da dupla caipira Alvarenga e Ranchinho, além de instrumentistas como Dilermando Reis, Garoto e seu conjunto Cordas Quentes, reforçado por Laurindo de Almeida, mais a atração do Teatro pelos Ares, estrelado por Plácido e Cordélia Ferreira.

Mas já a proximidade do 4ํaniversário da Nacional, a ser comemorado dali a seis meses, serviria de uma prévia do projeto a ser implantado na emissora incorporada à União. No domingo, 15 de setembro de 1940, ouvintes e convidados foram brindados com uma programação especial de 14 horas, devidamente patrocinadas, com início às $10 \mathrm{~h}$ da manhã e participação ao vivo do elenco da emissora, acrescido de novos nomes, destacando-se Joel e Gaúcho, Dorival Caymmi, Carmelia Alves, Vicente Celestino, o humorista Barbosa Junior, o cantor Albenzio Perrone e Victor Bacelar, entre outros. Orlando Silva merecia audição especial, "em nova fase ao microfone da PRE 8". As atrações musicais eram intercaladas com a participação do elenco do Teatro em Casa, agora reforçado com a contratação de Conchita de Moraes, Yara Sales, Luiz Tito, Amaral Gurgel e Floriano Faissal, que vinham se juntar a Celso Guimarães e Ismênia dos Santos, mais os locutores Aurélio de Andrade, Saint-Clair Lopes e Rubens Amaral.

O Desfile dos Grandes Programas da PRE 8 - “Realização 'extra' das principais audições especializadas da Rádio Nacional" - teve início às $17 \mathrm{~h} 30$, seguindo-se, às 18h15, Os Arranjos Modernos de Radamés - "velhas páginas brasileiras orquestradas em ritmos novos, na execução da Orques- 

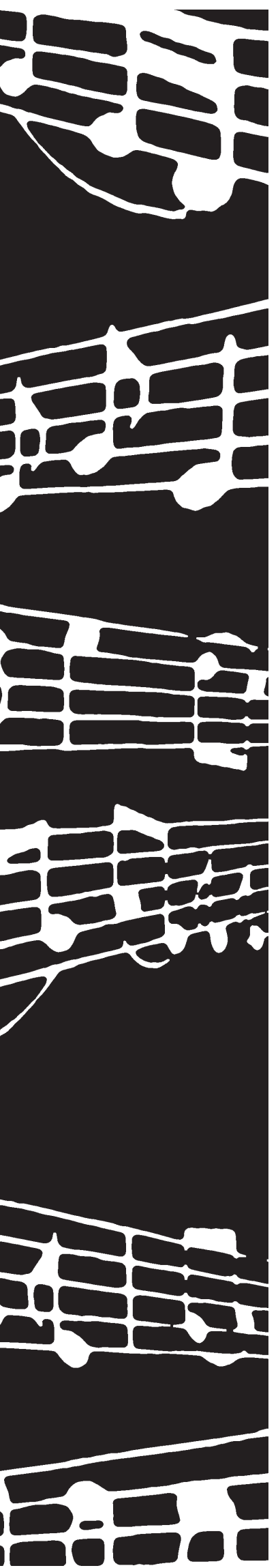

tra Carioca, sob a direção de Radamés". Às 19h soaram os acordes de Valsa, Divina Valsa!, programa produzido e apresentado por Lamartine Babo na série Vida Musical e Pitoresca dos Grandes Compositores.

Às $21 \mathrm{~h}$ entrava em cena Almirante e o seu Curiosidades Musicais, com o tema “A música dos sinos", sob o patrocínio da Philips do Brasil. Os produtos Eucalol ofereciam, 25 minutos depois, Instantâneos Sonoros do Brasil, nessa noite com o "quadro impressionista" intitulado Congadas, trabalho de Almirante e José Mauro, com arranjos de Radamés.

Para encerrar a programação, Ondas Sonoras de 1940, desfile preparado por José Mauro e Lamartine Babo, com músicas especialmente compostas por Dorival Caymmi, o próprio Lamartine e outros. A "apoteose final" foi reservada para o lançamento de "Onde o Céu Azul É Mais Azul”, de Alcir Pires Vermelho, João de Barro e Alberto Ribeiro, composta segundo o modelo de samba-exaltação que iria caracterizar o Estado Novo.

É interessante notar que, embora a música popular brasileira ocupasse lugar privilegiado, também havia espaço para intérpretes de jazz, música de salão, canções internacionais e solos de piano. E até a música erudita participava da festa: às $11 \mathrm{~h}$ da manhã era transmitido o Grande Concerto de Composições de Radamés Gnattali, pelo Quarteto de Cordas e a Orquestra Sinfônica da PRE 8, sob a regência de Romeu Ghipsman e do autor. Oferta de Cafiaspirina, locução de Saint-Clair Lopes.

O concerto durou uma hora; como toda a programação festiva desse dia, era umexemplo da filosofia que iria transformar a PRE 8 em fenômeno da comunicação brasileira, chegando a ser reconhecida em breve como a primeira emissora de rádio da América Latina e uma das cinco maiores do mundo.

Sem perda de tempo, Gilberto de Andrade aumenta a potência das ondas médias, promove a compra de antenas e transmissores de ondas curtas para as emissoras PRL 7, PRL 8, PRL 9, e expande as instalações da PRE 8. Reforma e multiplica estúdios
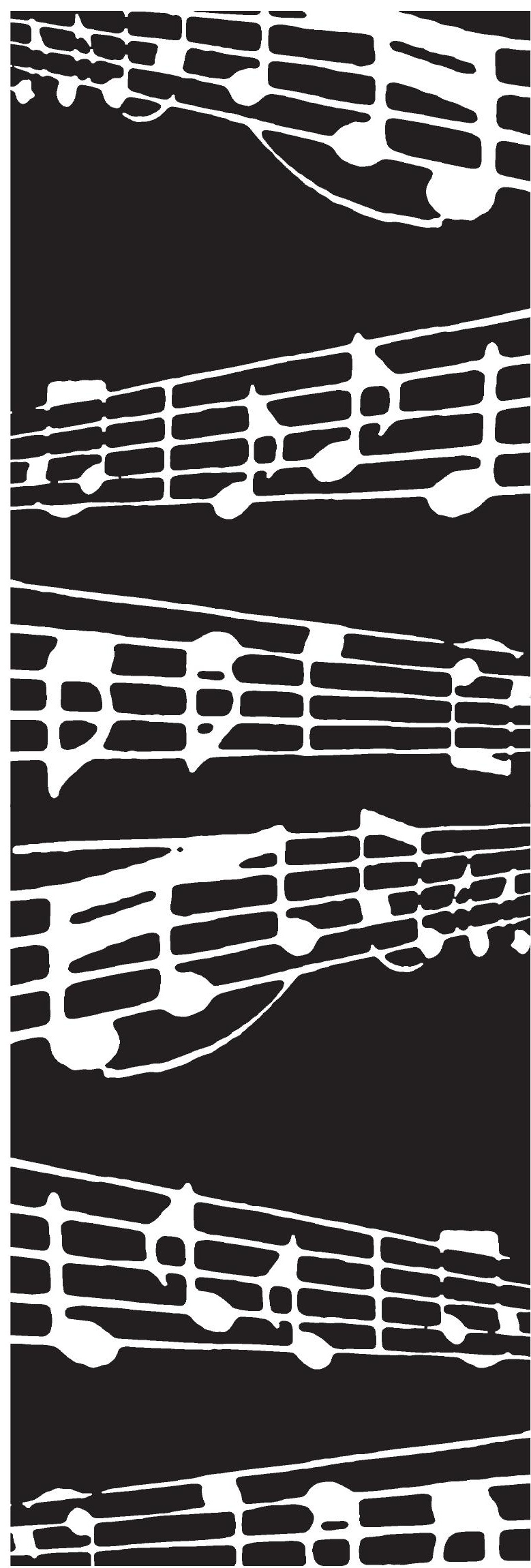
no $21^{\circ}$ andar e inicia a construção, em metade da área desse pavimento, de um novo e amplo auditório. Previsto para 498 poltronas estofadas, com espaço para lugares extras, tinha um palco-estúdio assentado sobre molas especiais para absorver vibrações. Quando necessário, o estúdio podia ser isolado da platéia pela descida automática de um grande vidro importado.

O espaço originalmente ocupado pela emissora no $22^{\circ}$ andar é reservado para o radioteatro, com a instalação de sala de ensaio, cabine de comando e um criativo estúdio cenográfico que reproduz uma casa. Ali são produzidos os efeitos de contraregra, como sinetas e campainhas, passos no jardim de cascalho ou o mergulho de um corpo na água - graças a um paralelepípedo atirado no tanque.

O sucesso de Em Busca da Felicidade, novela cubana adaptada por Gilberto Martins e patrocinada por Colgate-Palmolive, abre em 1941 outro filão comercial a sustentar a filosofia administrativa implantada pelo diretor e logo absorvida por seus principais colaboradores, responsáveis pela gerência dos departamentos que norteiam a emissora. Uma estratégia que nossos contemporâneos chamariam de marketing, mas que foi traduzida de modo mais simples por Paulo Tapajós, cantor, assistente de direção e mais tarde chefe do departamento musical da estação: “Tudo tinha que ser sustentado pelo faturamento global da Rádio Nacional” (depoimento gravado, 19/ago./1974).

Daí a preocupação do administrador com o ecletismo da programação, de modo que um programa econômico em talentos como as audições da dupla Jararaca e Ratinho, que envolvia apenas o regional e um locutor, desse uma margem de lucro capaz de cobrir o déficit de programas culturais como A Universidade do $A r$, ou a série Ondas Musicais, com a Orquestra Sinfônica regida pelo maestro Léo Peracchi.

Então acontece o lançamento de uma produção destinada a deixar traços profundos na cultura brasileira. Trata-se do programa semanal Um Milhão de Melodias, estreado em 6 de janeiro de 1943.

\section{A USINA DE SONS ENTRA EM EBULIÇÃO}

Um Milhão de Melodias foi escolhido como principal veículo de lançamento no Brasil de Coca-Cola, "a pausa que refresca". O adjetivo “borbulhante" devia pontuar a atmosfera do programa, efeito conseguido através da harpa dedilhada por Elza Guarnieri nas passagens orquestrais das vinhetas e do insinuante prefixo escrito por Radamés, também responsável por nove arranjos semanais. Pela primeira vez no rádio brasileiro, o anunciante merecia tratamento sonoro equivalente ao das estrelas do programa.

O diretor artístico José Mauro integrava a equipe de produção, com o maestro e arranjador e o discotecário Haroldo Barbosa, ao qual cabia a indicação de pelo menos duas músicas atuais, duas antigas, e em geral três estrangeiras de grande sucesso. Paulo Tapajós estreava em seu novo contrato, aceitando proposta de Gilberto de Andrade para as funções de cantor e assistente de direção.

Entre as inovações do programa estava, em primeiro lugar, a montagem de uma orquestra comparável à de Benny Goodman. Mas o modelo norte-americano, representativo do jazz, não servia para Um Milhão de Melodias. Segundo Radamés, era preciso uma orquestra capaz de executar a música popular de qualquer tipo e país, mas centrada numa formação ligada às fontes de nossas sonoridades. O núcleo da orquestra brasileira devia contar com dois violões, cavaquinho, contrabaixo acústico, mais um baterista completo como Luciano Perrone, capaz de tocar vibrafone, bells, tímpano, acompanhado de ritmistas como João da Baiana (pandeiro), Heitor dos Prazeres (caixeta ou prato de louça percutido com faca) e o ganzá de Bide (Alcebíades Barcelos, 1902-75).

Os dois violões foram entregues a $\mathrm{Ga}-$ roto (Anibal Augusto Sardinha, 1915-55)e Bola Sete (Djalma de Andrade, 1923-87), ficando o cavaquinho com José Menezes, embora a versatilidade dos três músicos 
permitisse ao maestro outras opções. Ao grupo viria se juntar o gaúcho Romeu Seibel, mais conhecido como Chiquinho do Acordeom (1928-?). Completavam a Orquestra Brasileira de Radamés naipes de violinos e violoncelos, a citada harpa, mais cinco saxofones, três pistões, dois trombones (os dois últimos logo aumentados para quatro, cada), além de três flautas, oboé, fagote e clarinete. Quando fossem necessários instrumentos não existentes na casa, como trompas ou contrafagotes, seriam convocados profissionais de fora, pagos mediante cachê.

A segunda novidade trazida pelo programa de Coca-Cola dizia respeito a interpretações exclusivas, vozes que se tornassem marcas do programa. Artistas da casa foram harmonizados para cantar juntos, surgindo As Três Marias, originalmente com Marilia Batista, Bidu Reis e Salomé Cotelli, esta logo substituída por Regina Célia, e o Trio Melodia (Albertinho Fortuna, Nuno Roland e Paulo Tapajós). Mais tarde, com a contratação do Trio Madrigal, egresso da Mayrink, foi possível unir de forma perfeita as vozes masculinas e femininas, formando um sexteto solicitado para diversas gravações comerciais.

A terceira inovação do programa residia nas versões em português para os sucessos internacionais. A intenção era, ao mesmo tempo, nacionalista e comunicativa, evitando que o desconhecimento das letras das canções dispersasse o ouvinte e desse ao programa um cunho elitista. Falando inglês, francês e espanhol, Haroldo Barbosa chegou a escrever mais de 600 versões de grandes sucessos. Muitos deles chegaram ao disco na voz de Francisco Alves, que vendeu quase 200 mil exemplares em 78 rotações de "Quantas São" verdadeira reinvenção do foxtrote "Jingle, Jangle, Jingle".

Como de hábito na época, os programas tinham de ser ensaiados e cronometrados para que nada desse errado na hora da transmissão ao vivo. Os problemas começavam pelo posicionamento de microfones num programa de grande orquestra e numerosos solistas, diante da disponibilidade de apenas quatro entradas na mesa da técnica. A solução encontrada foi a utilização de dois microfones em paralelo em cada entrada, dobrando os recursos de captação.

Em entrevista de 1977, Paulo Tapajós relembrou, emocionado, o momento em que alguém sugeriu um recurso comum em cinema, mas inédito em estúdio de rádio: a montagem de um microfone sobre uma haste móvel e longa, deslocando-se sobre rodas de borracha - a "girafa". Mas, para que a idéia funcionasse, foi necessário quadricular o chão do estúdio, em linhas horizontais e verticais, identificando com letra e número a posição de cada instrumento a ser captado, como no joguinho de batalha naval. Instalou-se em um ponto mais alto um segundo maestro - no caso, Léo Peracchi - com a partitura do programa, para comandar na hora precisa o movimento da "girafa" em direção ao solista.

Cada audição de Um Milhão de Melodias era gravada em discos de acetato de 16 polegadas. Depois a equipe de produção se reunia na discoteca para avaliar o que fora transmitido. Dali saíam críticas, sugestões e modificações para o aperfeiçoamento do produto radiofônico da PRE 8.

Tantos cuidados acostumavam o ouvinte a uma linguagem mais sofisticada e criativa e a uma gama musical de estilos, gêneros e épocas diversas, permitindo que cada um escolhesse o que mais lhe agradasse.

$\mathrm{Na}$ verdade, programas como $\mathrm{Um} \mathrm{Mi}$ lhão de Melodias constituíam um ponto de encontro entre a tradição e a renovação, trazendo de volta valores quase esquecidos - como as composições de Ernesto Nazareth, Catulo, João Pernambuco ou Chiquinha Gonzaga -, em contraste com obras que abriam novos horizontes - como os sambas de Custódio Mesquita e Ary Barroso, e as ousadias de Ernesto Lecuona, Cole Porter ou George Gershwin.

A preocupação com a memória musical do país estava presente em outras audições da Nacional, produzidas em várias épocas - A Turma do Sereno, Canção Antiga, Audições Pixinguinha, Canção da Lembrança, A Lira de Xopotó (produzido por Paulo Roberto para homenagear as 
bandinhas do interior). Ou nos programas montados, narrados por Almirante, como História das Orquestras e Músicos do Brasil, História do Rio de Janeiro pela Música, Recolhendo Folclore, e o orgulho de Renato Murce, Alma do Sertão.

Mas a preservação não excluía propostas de novas roupagens para a música brasileira, com as harmonizações ousadas de Os Cariocas, as dissonâncias do violonista e compositor Valzinho, autor de "Doce Veneno", as composições de Garoto, como "Duas Contas", e as audições do Trio Surdina (Garoto, Chiquinho do Acordeom e Fafá Lemos e seu violino), mais os desafios orquestrais de Quando os Maestros se Encontram.

Eram as sementes que iriam florescer adiante, acompanhando o amadurecimento de rapazes e moças que cresceram ouvindo rádio, quer morassem junto ao mar de Copacabana, quer nascidos em Arapiraca, São Bento do Una ou Santo Amaro da Purificação. De suas vozes, seus discos e shows, seus pianos ou violões, sai também um tributo diário ao veículo que há oitenta anos nos acompanha, sem exigir mais do que o girar de um botão.

\section{A MINA ABANDONADA}

Ao longo da década de 1960 a hegemonia da televisão obrigou o rádio a se contentar com a notícia e a prestação de servi- ços, sobrando cada vez menos espaço para a radiofonia como meio de expressão. A dependência da música enlatada abriu caminho à promoção de sucessos indicados pelas gravadoras, através do sistema de play-list. Resta aos independentes, na maioria dos casos, pagar ou correr.

Para os apreciadores de música erudita não sobram transmissões em ondas médias. Apenas duas ou três FMs divulgam esse material em sua programação - como a Rádio Cultura de São Paulo e a MEC do Rio, mais uma ou outra emissora universitária, como a da Universidade Católica de Porto Alegre.

A insistência do Sistema Jornal do Brasil com a música erudita teve seu clímax na programação noturna Clássicos em FM, depois transferida para a Opus 90, interrompida por falta de apoio comercial. Mas retomada, mais tarde, com a parceria de $O$ Dia, e novamente fracassada.

Diante desse quadro, qual será o desafio para os que acreditam no rádio como um veículo criativo, que ainda pode excitar a sensibilidade e a imaginação dos que vivem o século XXI?

É possível que a resposta esteja sendo formulada nas pequenas rádios comunitárias ou universitárias que tentam abrir novos caminhos, apesar das limitações do cotidiano. Para esses, talvez valha como estímulo a opinião de Orson Welles sobre o veículo que ele marcou com o impacto da transmissão de A Guerra dos Mundos, em 1938: “O rádio é hoje uma mina abandonada".

\section{BIBLIOGRAFIA}

BOGDANOVICH, Peter. Este é Orson Welles. São Paulo, Globo, 1995.

CALABRE, Lia. A Era do Rádio. Rio de Janeiro, Jorge Zahar, 2002, p. 17.

FEDERIC0, Maria Elvira Bonavita. História da Comunicação Rádio e TV no Brasil. Rio de Janeiro, Vozes, 1982, p. 44-5.

GUIMARÃES, Celso. "A Nacional Tem sua História Também...", in Revista da Rádio Nacional, ano 1, n. 5. Rio de Janeiro, dez./1950.

LOPES, Saint-Clair. Radiodifusão. Meio Século a Serviço da Integração Nacional. Rio de Janeiro, Abert, 1972.

MURCE, Renato. Bastidores do Rádio. Rio de Janeiro, Imago Editora, 1976, pp. 20-1.

ROQUETTE-PINTO, Edgar. Seixos Rolados. Rio de Janeiro, 1927 (Col. Ensaios Brasileiros).

"Discurso de Agradecimento na Associação Brasileira de Telecomunicações". Rio de Janeiro, 1953. 